\title{
ANALISA PRODUKSI PANAS RADIOGENIK, DENSITAS DAN KECEPATAN SEISMIK DARI SINGKAPAN BATU GRANIT PANAS BUMI NYELANDING, BANGKA SELATAN
}

\author{
Rahmat Nawi Siregar1, Maria Evalina Purba², Ahmat Munawir Siregar ${ }^{3}$ \\ Institut Teknologi Sumatera ${ }^{1,2}$ \\ Universitas Jambi ${ }^{3}$ \\ rahmat.siregar@fi.itera.ac.id ${ }^{1}$
}

\begin{abstract}
The purpose of this study was to determine the analysis of radiogenic heat production, density and seismic velocity of the outcrops of the South Bangka Nyelanding geothermal rock. The X-ray Fluorescence $(X R F)$ method is applied to obtain heat-carrying radioactive elements in the form of Uranium, Thorium and Potassium and other oxides which are useful for studying seismic density and velocity. The main oxides used in this study were $\mathrm{SiO}$, TiO2, Al2O3, $\mathrm{MgO}, \mathrm{CaO}, \mathrm{K} 2 \mathrm{O}$ and P2O5. The results showed that the density increased from the composition of the mineral felsic (acid) - mafic (base). Conclusion, as for the relationship with heat production, the SiO2 and P2O5 elements experienced a significant decrease compared to other oxides. As for seismic velocity, the results show that seismic velocity has a strong correlation with density.
\end{abstract}

Keywords: Radiogenic Heat Production, Seismic Velocity, Density, Oxides

Abstrak: Tujuan penelitian ini adalah untuk mengetahui analisa produksi panas radiogenik, densitas dan kecepatan seismik dari singkapan batu granit panas bumi Nyelanding Bangka Selatan. Metode Xray Fluoresncence (XRF) diaplikasikan untuk mendapatkan unsur radioaktif pembawa panas berupa Uranium, Thorium dan Potassium serta oksida lainnya yang berguna untuk mempelajari densitas serta kecepatan seismic. Oksida utama yang digunakan dalam penelitian ini adalah $\mathrm{SiO}_{2}, \mathrm{TiO}_{2}, \mathrm{Al}_{2} \mathrm{O}_{3}, \mathrm{MgO}_{\text {, }}$ $\mathrm{CaO}, \mathrm{K}_{2} \mathrm{O}$ dan $\mathrm{P}_{2} \mathrm{O}_{5}$. Hasil penelitian menunjukkan bahwa densitas meningkat dari komposisi mineral felsik (asam) - mafik (basa). Simpulan, adapun hubungannya dengan produksi panas, unsur $\mathrm{SiO}_{2}$ dan $\mathrm{P}_{2} \mathrm{O}_{5}$ mengalami penurunan yang siginifkan dibanding oksida lain. Adapun untuk kecepatan seismic, hasil menunjukkan bahwa kecepatan seismic memiliki korelasi yang kuat dengan densitas.

Kata Kunci: Radiogenic Heat Production, Seismic Velocity, Density, Oxides

\section{PENDAHULUAN}

Manifestasi panas bumi Nyelanding merupakan salah satu panas bumi radiogenik yang terdapat di Pulau Bangka (Siregar, Kurniawan, 2018). Panas bumi radiogenik merupakan panas bumi yang berasal dari peluruhan unsur radioaktif batuan kerak bumi. Uranium, Thorium dan Potassium merupakan unsur yang sangat berpengaruh dalam pembentukan panas, sehingga bisa dikategorikan sebagai unsur utama dalam menghasilkan panas radiogenik (Rybach, Bunterbath, 1982). Salah satu batuan yang sering sekali mangandung unsur radioaktif adalah batu granit (Singh \& Vallinayagam, 2016; Slagstad, 2008; Zhang et al., 2020) yang tersebar di sebagian besar Pulau Bangka. Kajian petrograafi dan geokimia batuan granit di Pulau Bangka menunjukkan bahwa tipe granitoid Bangka Tengah dan Timur (Belinyu) diklasifikasikan sebagai tipologi granitoid tipe I dicirikan proporsi magnetit, magnesian dan lebih primitive, sedang tipe $S$ pada granitoir Bangka Selatan dan Barat dicirikan oleh tingginya $\mathrm{K}_{2} \mathrm{O}$ (Widana, 2013). Batu granit di Pulau Bangka juga mempunyai kandungan Potassium yang sangat tinggi dan teridentifikasi berasal dari dua sumber utama, yaitu batuan dari kerak benua bagian bawah dan kerak benua bagian atas $(<40 \mathrm{~km})$ (Sitha \& Setijadji, 2009). Penelitian lain juga menunjukkan bahwa Granitoid Bangka Utara dan 
Tengah merupakan percampuran kerak mantel dengan afinitas Calc-Alkaline, sedangkan di granitoid Bangka Selatan dan Barat asal kerak dengan afinitas High-K Calc-Alkaline sebagai Tipe S (Setiawan \& Priadi, 2016).

Kandungan unsur radioaktif dari batu granit telah banyak diteliti dengan menggunakan berbagai metode. Hasil penelitian dari 125 sampel batuan granit di Pulau Bangka (Ngadenin et al., 2014) menunjukkan kandungan Thorium yang sangat tinggi dari granit Gadung (76 ppm), granit Bebuluh $(23,33)$, granit Mangol (42 ppm), granit Pemali $(35,40$ ppm), granit Jebus (85,96 ppm), granit Pelangas $(66,73)$ dan granit Menumbing $(67,03$ ppm). Rata - rata kandungan unsur radioaktif dari batu granit di Bangka Selatan dan Barat menunjukkan angka yang sangat tinggi, yaitu Uranium 10,27 ppm, Thorium 79,6 ppm dan Potassium 3,10 \%. Sedangkan untuk daerah Bangka Utara dan Bangka Tengah mengandung Uranium yang sangat tinggi, yaitu 87,79 ppm, Thorium 65,7 ppm dan Potassium 1,93\% (Setiawan \& Priadi, 2016).

Tingginya kandungan unsur radioaktif dari batuan granit Pulau Bangka menarik minat Penulis untuk mempelajari lebih lanjut terkait produksi panas yang dihasilkan dari singkapan batu granit di sekitar panas bumi Nyelanding. Selain itu, analisa produksi panas dengan densitas serta kecepatan seismik terhadap oksida batu granit menarik untuk diteliti.

\section{LANDASAN TEORI}

Produksi panas radiogenic merupakan salah satu kunci yang sangat penting untuk mengetahui suhu, aliran panas, serta evolusi dari batuan penyusun kerak dan mantel bumi (Sclater et al., 1980). Batuan vulkanik dan plutionik menjadi batu yang paling sering mempunyai kandungan panas radiogenic (Abbady \& Al-Ghamdi, 2018; Ashwal et al., 1987; Brady et al., 2006; CHIOZZI et al., 2008; Singh \& Vallinayagam, 2016). Adapun unsur pembawa batuan panas radiogenic adalah Thorium, Uranium dan Potassium (Aydin et al., 2007; Baltaztis. Esson, J. Mitropulos, 1992; He et al., 2010; Lamas et al., 2015), walaupun unsur lain juga mempunyai kontribusi yang sangat kecil. Konsentrasi U, Th, dan $\mathrm{K}$ dari beberapa batuan serta produksi panas yang dihasilkan disajikan di

Table 1. Konsentrasi radioactif dan produksi panas (Brown \& Musset, 1993)

\begin{tabular}{lllllll}
\hline No & Material & $\mathrm{U}(\mathrm{ppm})$ & $\mathrm{Th}(\mathrm{ppm})$ & $\mathrm{K}(\%)$ & $\mathrm{K} / \mathrm{U}$ & $\begin{array}{l}\text { Heat } \\
\text { Productivity } \\
\end{array}$ \\
& & & & & $\left(\mu \mathrm{Wm}^{-3}\right)$ \\
\hline 1 & Bulk Earth & 0.02 & 0.02 & 0.02 & 10000 & 0.014 \\
2 & Gabrro & 0.05 & 0.15 & 0.08 & 16000 & 0.03 \\
3 & Granodiorite & 1.6 & 6.2 & 2.1 & 13125 & 1.0 \\
4 & Granulite & 0.2 & 0.7 & 0.25 & 12500 & 0.13 \\
5 & Carbonaceous & 0.02 & 0.07 & 0.04 & 20000 & 0.01 \\
& chondrite & & & & & \\
6 & Ordinary chondrite & 0.015 & 0.046 & 0.09 & 60000 & 0.015 \\
7 & Iron meteorite & negligible & negligible & negligible & - & negligible \\
\hline
\end{tabular}

Produksi panas sebagai fungsi unsur oksida telah menjadi pembahasan yang menarik belakangan ini. Produksi panas radiogenic mempunyai hubungan empiris dengan besaran - besaran fisis yang lain seperti densitas dan kecepatan seismic sebagaiman telah diajukan oleh Rybach (Rybach, 1978). Hubungan tersebut bias digunakan untuk estimasi 
sebaran produksi panas secara lateral dan vertikal.

\section{METODE PENELITIAN Produksi Panas}

Produksi panas radiogenic bisa ditentukan dengan menggunakan hubungan matemasi antara komposisi kimia dan konsentrasi unsur radioaktif, dengan $C_{\mathrm{U}}$ adalah konsentrasi Uranium dalam part per million (ppm), $C_{\mathrm{Th}}$ konsentrasi Thorium dalam part per million (ppm) dan $C_{K}$ dalam $\%$. Produksi panas $A$ dinyatakan dalam $\mu \mathrm{Wm}^{-3}$.

$$
A=\rho\left(9,67 C_{U}+2,56 C_{T h}+2,89 C_{K}\right) 10^{-5}
$$

\section{Kecepatan seismik $\left(V_{P}\right)$}

Estimasi kecepatan seismic menggunakan model empiris yang telah dikalibrasi dengan menggunakan lebih dari 18.000 data batuan beku dari pangkalan data IGBA. Model empiris yang digunakan adalah, dengan masing masing konsentrasi setiap oksida adalah dalam persen dan $V_{p}$ dalam $\mathrm{km} / \mathrm{s}$.

$V_{p}=6,9-0,011 C_{\mathrm{SiO}_{2}}+0,037 C_{\mathrm{MgO}}+0,045 C_{\mathrm{CaO}}$

\section{Densitas}

Model densitas dari oksida terdapat 4 model, tergantung pada koefisien regresinya. Adapun model densitas yang digunakan pada penelitian ini adalah model 4, dengan indeks geokimianya adalah, dengan $\mathrm{n}$ adalah jumlah mol dari komponen oksida serta $\mathrm{FeO}^{\mathrm{T}}$ adalah total besi.

$\rho=2468,5+174,7 \mathrm{Fe} *-12 \mathrm{MALI}+49,6$ ASI +636 maficity

(3)

$$
\begin{aligned}
& \mathrm{Fe}^{*} \quad \text { (iron } \\
& \mathrm{C}_{\mathrm{FeO}^{\mathrm{T}}}\left(\mathrm{C}_{\mathrm{FeO}^{\mathrm{T}}}+\mathrm{C}_{\mathrm{MgO}}\right)^{-1} \\
& \mathrm{MALI} \quad \text { (modified alkali-lime })= \\
& \mathrm{C}_{\mathrm{Na}_{2} \mathrm{O}}+C_{\mathrm{K}_{2} \mathrm{O}}-\mathrm{C}_{\mathrm{NaO}}
\end{aligned}
$$

ASI (Alumina saturation index $)=$ $n_{A l}\left(n_{C a}-1,67 n_{p}+n_{N a}+n_{K}\right)^{-1}$

Maficity $=n_{F e}+n_{M g}+n_{T i}$

\section{HASIL PENELITIAN}

Unsur utama kimia yang digunakan dalam penelitian ini ialah $\mathrm{SiO}_{2}, \mathrm{TiO}_{2}, \mathrm{Al}_{2} \mathrm{O}_{3}, \mathrm{Fe}_{2} \mathrm{O}_{3}, \mathrm{MgO}, \mathrm{CaO}, \mathrm{K}_{2} \mathrm{O}$, dan $\mathrm{P}_{2} \mathrm{O}_{5}$ untuk meihat gambaran komposisi mineral dari batuan. Dalam hal ini terdapat 3 bentuk grafik dari 9 unsur utama kimia yang terdiri atas grafik hubungan antara densitas dengan 9 unsur utama kimia, kecepatan seismik dengan 9 unsur kimia serta produksi panas dengan 9 unsur utama kimia.

Berdasarkan grafik pada gambar 1, diperoleh kesimpulan bahwa grafik densitas dari kesembilan unsur utama kimia mengalami pergerakan yang berbeda antara satu dengan yang lain,khususnya di grafik hubungan antara densitas dengan unsur $\mathrm{SiO}_{2}$, karena pada grafik ini mengalami penurunan yang signifikan dari grafik yang terdiri unsur yang lain. Untuk grafik yang mengalami peningkatan unsur secara signifikan terjadi pada unsur $\mathrm{Fe}_{2} \mathrm{O}_{3}, \mathrm{MgO}, \mathrm{CaO}, \mathrm{K}_{2} \mathrm{O}$ serta $\mathrm{P}_{2} \mathrm{O}_{5}$,sedangkan untuk unsur $\mathrm{Al}_{2} \mathrm{O}_{3}$ terjadi peningkatan yang tidak signifikan. Densitas meningkat dari komposisi mineral felsik (asam)-mafik (basa).

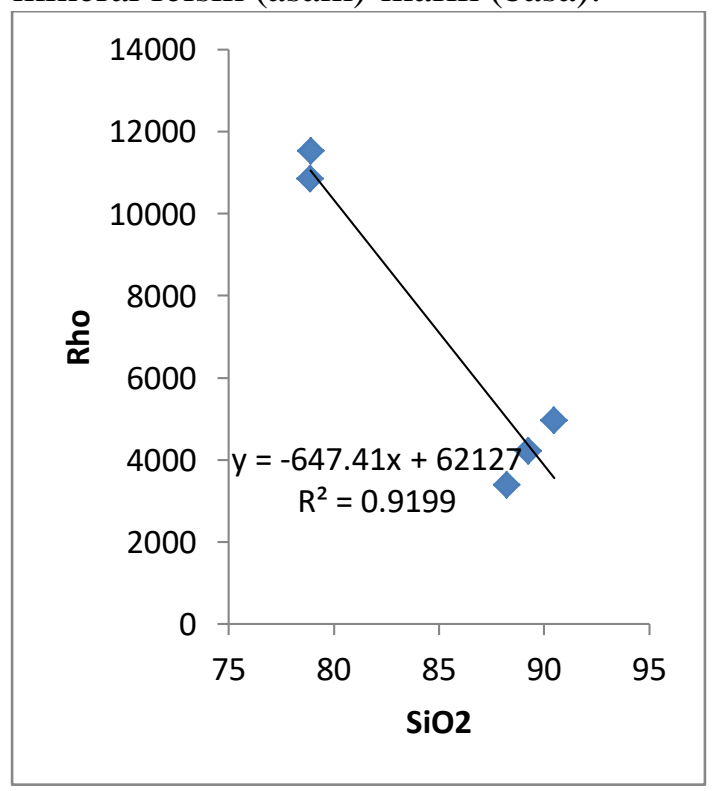



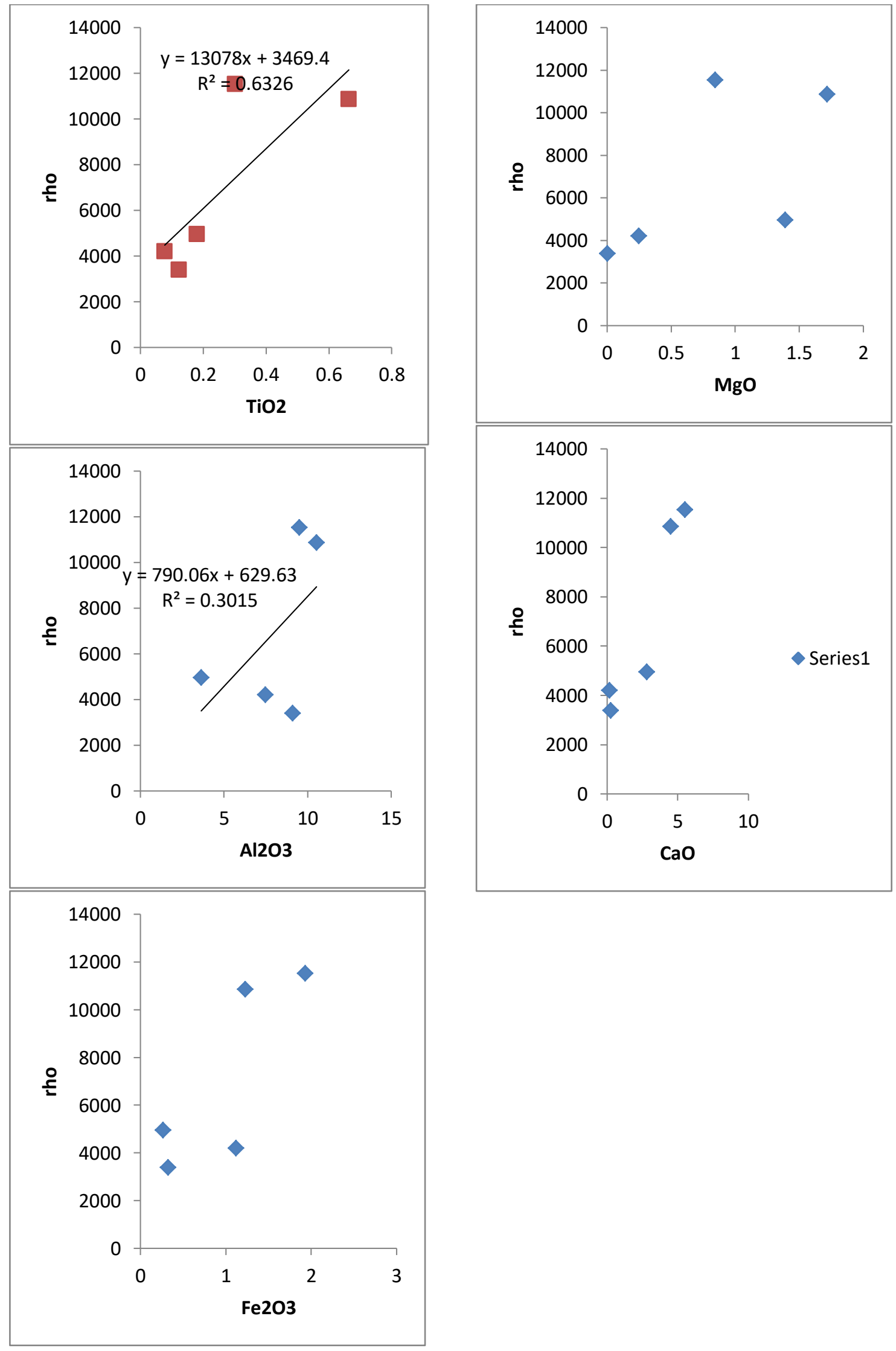


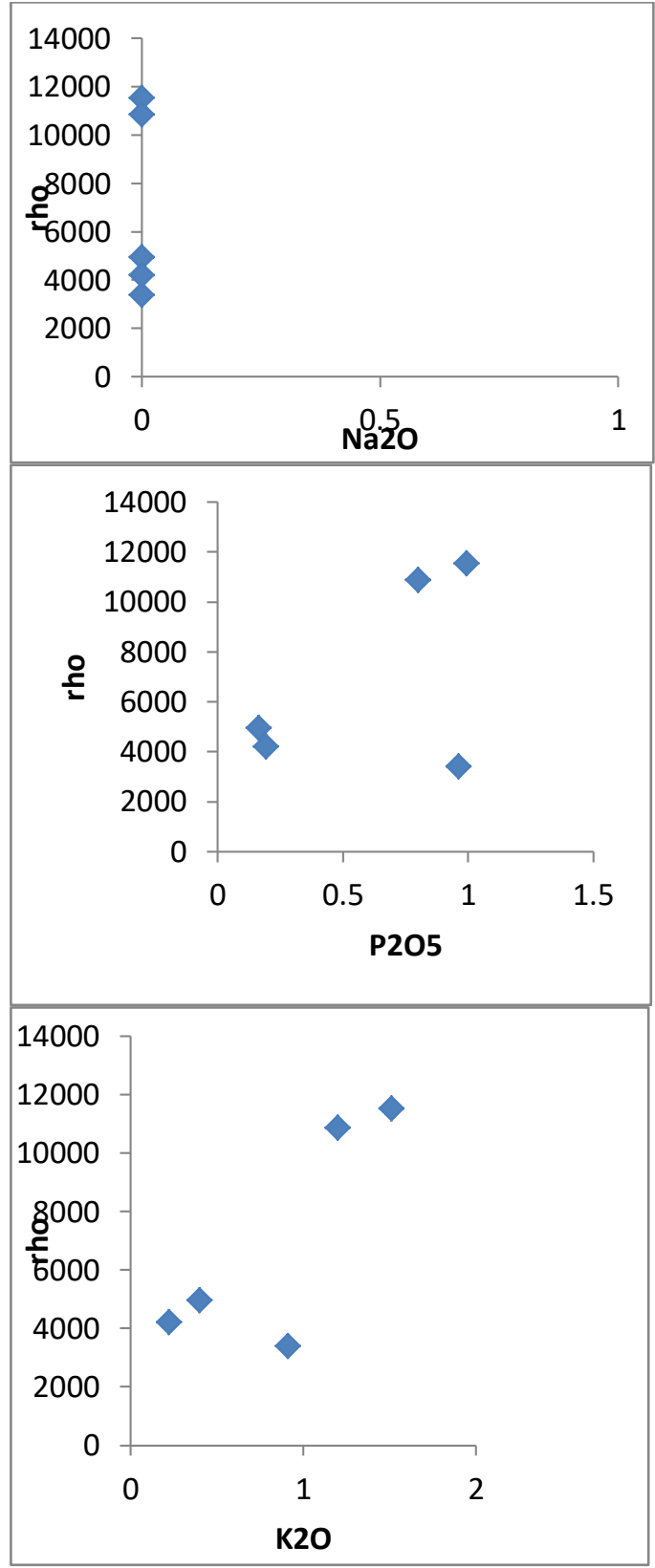

Gambar 1. Grafik hubungan antara densitas terhadap 9 oksida

Grafik yang mengalami penurun yang signifikan dari seluruh unsur utama kimia yaitu unsur $\mathrm{SiO}_{2}$ serta $\mathrm{P}_{2} \mathrm{O}_{5}$, sedangkan unsur $\mathrm{TiO}_{2}, \mathrm{Fe}_{2} \mathrm{O}_{3}, \mathrm{MgO}, \mathrm{CaO}$, serta $\mathrm{K}_{2} \mathrm{O}$ mengalami peningkatan yang cukup signifikan. Tetapi peningkatan pada unsur $\mathrm{K}_{2} \mathrm{O}$ dan $\mathrm{CaO}$ tidak terlalu tinggi,bentuknya masih lebih landai dari seluruh grafik unsur.
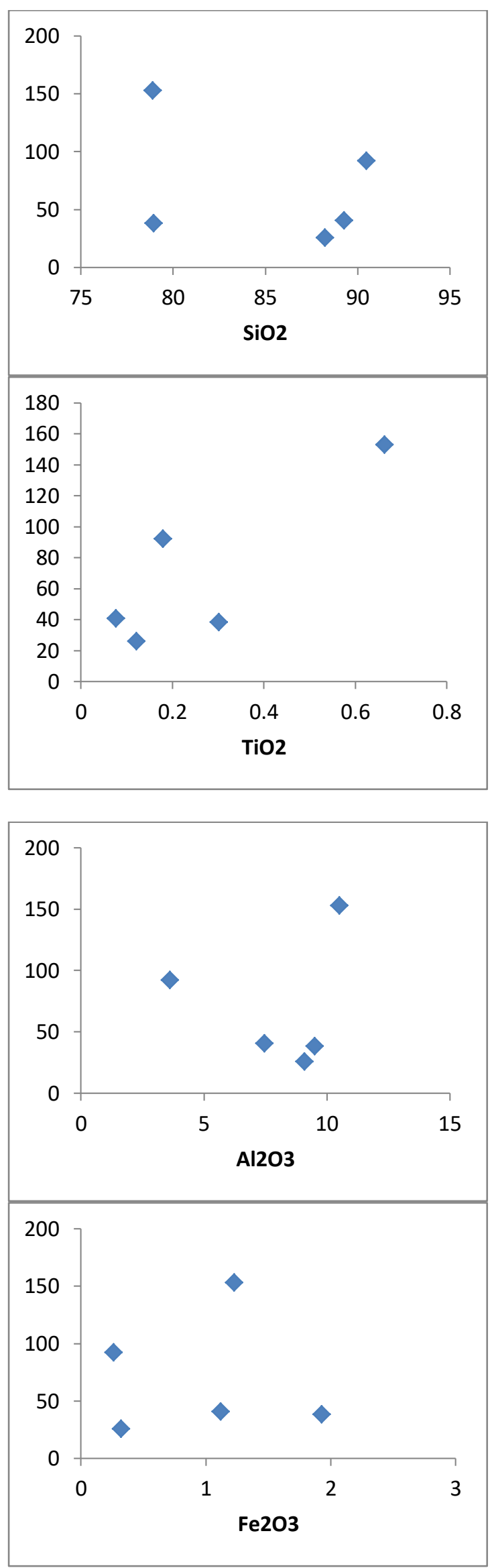

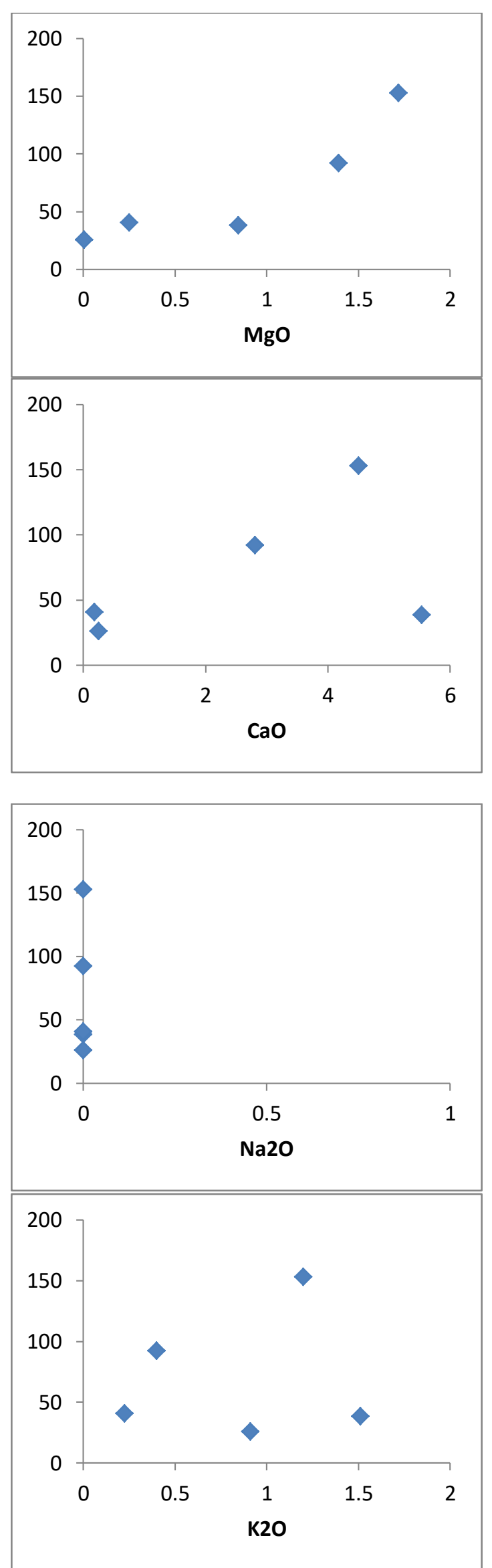

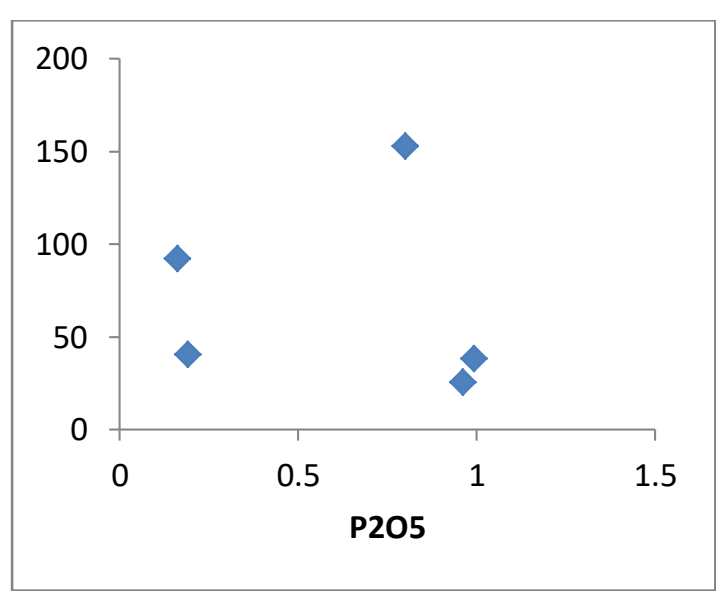

Gambar 2. Grafik hubungan antara produksi panas terhadap 9 oksida

Hubungan antara kecepatan seismik dengan unsur 9 unsur utama kimia menghasilkan bentuk grafik yang sama dengan grafik hubungan antara densitas terhadap 9 unsur utama kimia. Hal ini menunjukkan bahwa kecepatan seismik memilki korelasi yang kuat dengan densitas, dimana semakin tinggi densitas maka semakin tinggi pula kecepatan seismik yang dilakukan. Dalam hal ini densitas berbicara tentang porositas batuan,sedangkan kecepatan seismik berbicara tentang elastitisitas batuan.

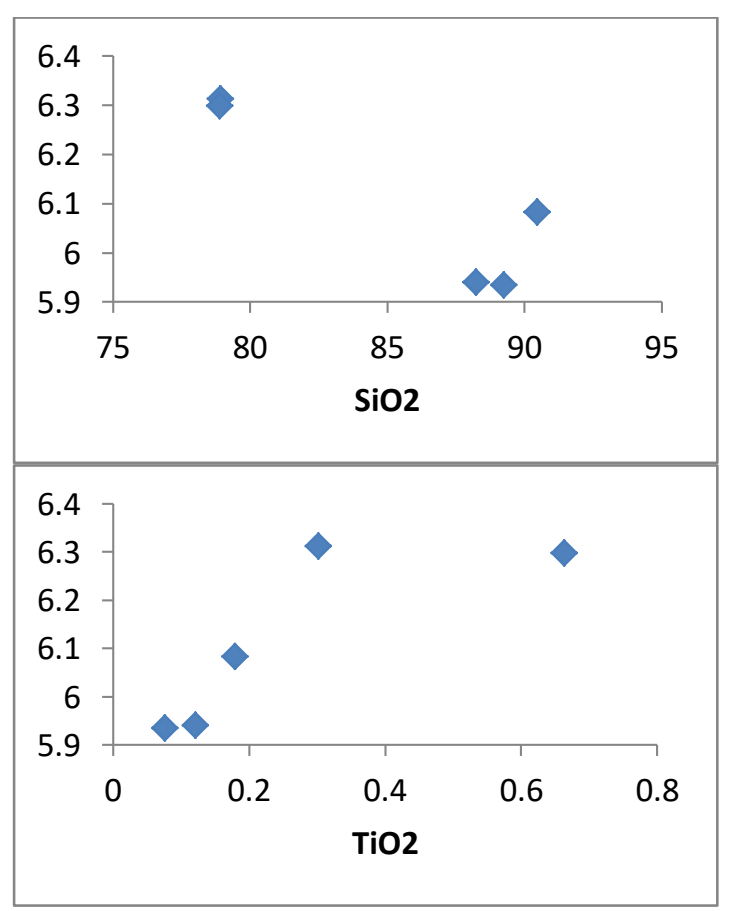



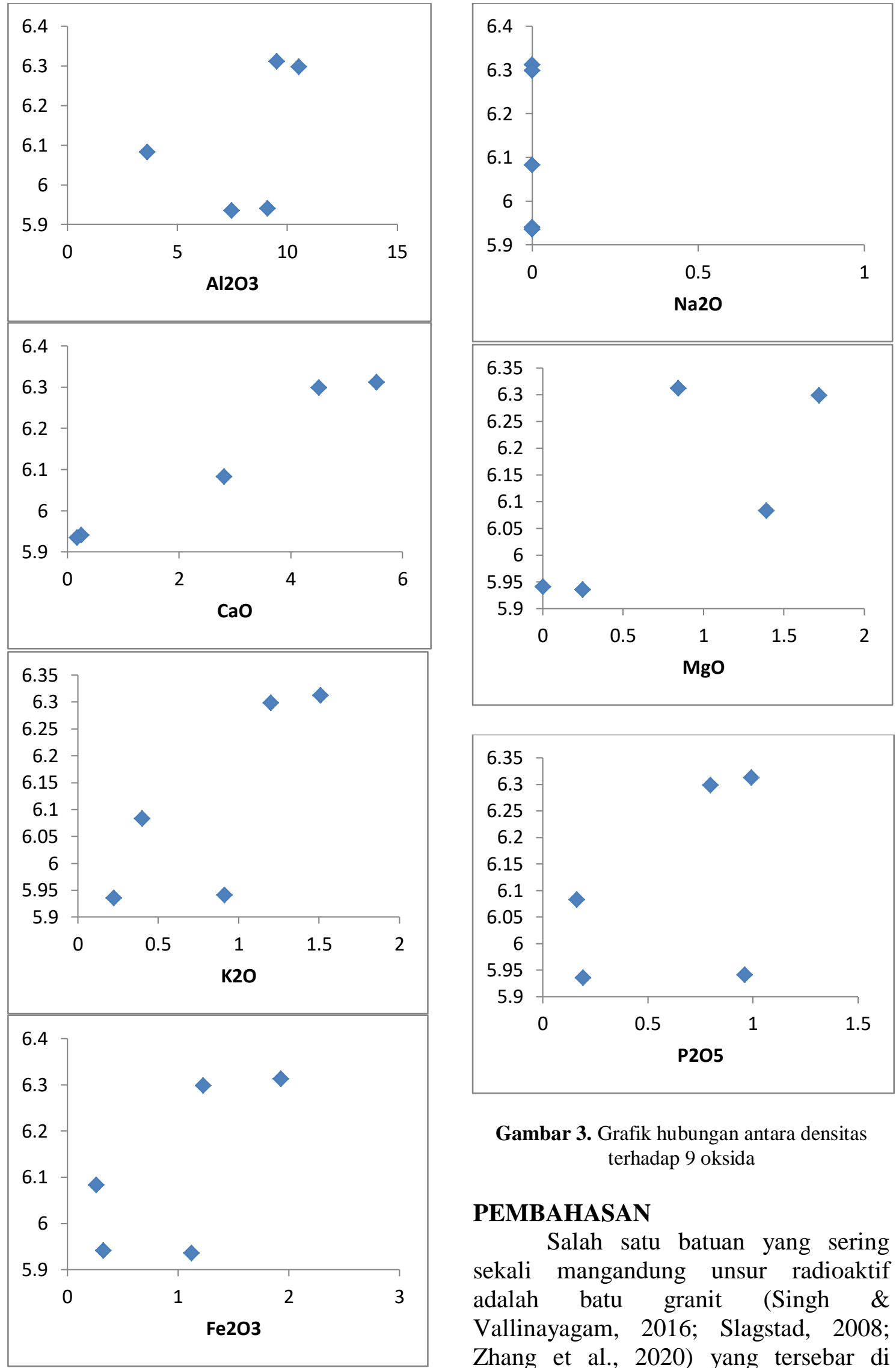

Gambar 3. Grafik hubungan antara densitas terhadap 9 oksida

\section{PEMBAHASAN}

Salah satu batuan yang sering sekali mangandung unsur radioaktif adalah batu granit (Singh \& Vallinayagam, 2016; Slagstad, 2008; Zhang et al., 2020) yang tersebar di sebagian besar Pulau Bangka. Kajian petrograafi dan geokimia batuan granit di 
Pulau Bangka menunjukkan bahwa tipe granitoid Bangka Tengah dan Timur (Belinyu) diklasifikasikan sebagai tipologi granitoid tipe I dicirikan proporsi magnetit, magnesian dan lebih primitive, sedang tipe $S$ pada granitoir Bangka Selatan dan Barat dicirikan oleh tingginya $\mathrm{K}_{2} \mathrm{O}$ (Widana, 2013). Batu granit di Pulau Bangka juga mempunyai kandungan Potassium yang sangat tinggi dan teridentifikasi berasal dari dua sumber utama, yaitu batuan dari kerak benua bagian bawah dan kerak benua bagian atas $(<40 \mathrm{~km})$ (Sitha \& Setijadji, 2009). Penelitian lain juga menunjukkan bahwa Granitoid Bangka Utara dan Tengah merupakan percampuran kerak mantel dengan afinitas Calc-Alkaline, sedangkan di granitoid Bangka Selatan dan Barat asal kerak dengan afinitas High-K Calc-Alkaline sebagai Tipe S (Setiawan \& Priadi, 2016).

Kandungan unsur radioaktif dari batu granit telah banyak diteliti dengan menggunakan berbagai metode. Hasil penelitian dari 125 sampel batuan granit di Pulau Bangka (Ngadenin et al., 2014) menunjukkan kandungan Thorium yang sangat tinggi dari granit Gadung (76 ppm), granit Bebuluh $(23,33)$, granit Mangol (42 ppm), granit Pemali (35,40 ppm), granit Jebus (85,96 ppm), granit Pelangas $(66,73)$ dan granit Menumbing $(67,03 \mathrm{ppm})$. Rata - rata kandungan unsur radioaktif dari batu granit di Bangka Selatan dan Barat menunjukkan angka yang sangat tinggi, yaitu Uranium 10,27 ppm, Thorium 79,6 ppm dan Potassium 3,10 \%. Sedangkan untuk daerah Bangka Utara dan Bangka Tengah mengandung Uranium yang sangat tinggi, yaitu 87,79 ppm, Thorium 65,7 ppm dan Potassium 1,93\% (Setiawan \& Priadi, 2016).

\section{SIMPULAN}

Jika di tinjau secara garis besar dari perbedaan antara 3 bentuk grafik dari 9 unsur utama kimia,maka dapat tarik hipotesis sementara bahwa unsur $\mathrm{SiO}_{2}$ mengalami penurunan yang signifikan dari 3 perbandingan grafik tersebut, baik densitas, produksi panas serta kecepatan seismik, sedangkan unsur $\mathrm{TiO}_{2}$ mengalami peningkatan yang sama dari 3 bentuk grafik perbandingan. Untuk unsur $\mathrm{Al}_{2} \mathrm{O}_{3}$ juga mengalami peningkatan sedang untuk grafik hubungan densitas serta produksi panas tetapi mengalami peningkatan yang sangat tinggi di grafik hubungan kecepatan seismik. Berbeda dengan unsur $\mathrm{Fe}_{3} \mathrm{O}_{3}$, unsur ini mengalami peningkatan yang cukup tinggi di grafik densitas serta kecepatan seismik, sedangkan untuk grafik produksi panas pergerakan naiknya cukup landai.

Unsur $\mathrm{MgO}$ dan $\mathrm{CaO}$ mengalami bentuk peningkatan grafik yang signifikan dan seragam dari ketiga bentuk grafik hubungan : densitas, kecepatan seismik serta produksi panas. Bentuk grafik dari $\mathrm{K}_{2} \mathrm{O}$ memiliki bentuk grafik yang sama baik dari grafik densitas,produksi panas serta kecepatan seismik yaitu peningkatan terjadi sangat signifikan di grafik densitas serta kecepatan seismik ,sedangkan untuk grafik produksi panas peningkatannya cukup landai. Unsur yang paling mengalami pergerakan yang berbeda dari unsur yang lain yaitu unsur $\mathrm{P}_{2} \mathrm{O}_{5}$, dimana unsur ini mengalami peningkatan yang cukup curam dari grafik densitas dan kecepatan seismik tetapi hal tersebut tidak terjadi pada grafik produksi panas sehingga terjadi hubungan berbanding terbalik antara grafik produksi panas dengan densitas serta kecepatan seismik. Berdasarkan penjelasan tersebut,dapat disimpulkan bahwa komposisi mineral oksida mempengaruhi pergerakan dari kecepatan seismik terhadap densitas dalam produksi panas. 


\section{DAFTAR PUSTAKA}

Abbady, A. G. E., \& Al-Ghamdi, A. H. (2018). Heat Production Rate from Radioactive Elements of Granite Rocks in North and Southeastern Arabian Shield Kingdom of Saudi Arabia. Journal of Radiation Research and Applied Sciences, 11(4), 281-290. https://doi.org/10.1016/j.jrras.2018. 03.002

Ashwal, L. D., Morgan, P., Kelley, S. A., \& Percival, J. A. (1987). Heat Production in an Archean Crustal Profile and Implications for Heat Flow and Mobilization of HeatProducing Elements. Earth and Planetary Science Letters, 85(4), 439-450.

https://doi.org/10.1016/0012821X(87)90139-7

Aydin, A., Ferré, E. C., \& Aslan, Z. (2007). The Magnetic Susceptibility of Granitic Rocks as a Proxy for Geochemical Composition: Example from the Saruhan Granitoids, Ne Turkey the Magnetic Susceptibility of Granitic Rocks as a Proxy for Geochemical Composition: Example from the Saruhan Granitoi. Tectonophysics, 44(May 2007), 85-95. https://doi.org/10.1016/j.tecto.2007 .04 .009

Baltaztis. E, J., \& Mitropulos, E. (1992). The Main Granitic Intrusions of Greece: an Application of Trace Element Discrimination. Mineral Magazine, 56(December), 487-501

Behn, M., \& Kelemen, P, B. (2003). Relationship Between Seismic PWave Velocity and the Composition of Anhydrous Igneous and Meta-Igneous Rocks. Geochemistry, Geophysics, Geosistems, 1041(4)

Brady, R. J., Ducea, M. N., Kidder, S. B., \& Saleeby, J. B. (2006). The Distribution of Radiogenic Heat
Production as a Function of Depth in the Sierra Nevada Batholith, California. Lithos, 86(3-4), 292244.

https://www.sciencedirect.com/scie nce/article/pii/S002449370500130

1

Brown, G. ., \& Musset, A. . (1993). The Inaccessible Earth an integrated view to its (2nd ed.). Chapman \& Hall Row

Chiozzi, P., Pasquale, V., Verdoya, M., \& Furfaro, V. (2008). Hydrothermal Alteration Inferred from a Radiometric Survey on Lipari (Aeolian Islands, Italy). Environmental Semeiotics, 1(1), 70-82. https://doi.org/10.3383/es.1.1.5

Hasterok, D., \& Webb, J. (2017). On the Radiogenic Heat Production of Igneous Rocks. Geoscience Frontiers, 8(5), 919-940. https://doi.org/10.1016/j.gsf.2017.0 3.006

He, Z. Y., Xu, X. S., \& Niu, Y. (2010). Petrogenesis and Tectonic Significance of a Mesozoic Granite-Syenite-Gabbro

Association from Inland South China. Lithos, 119(3-4), 621-641. https://doi.org/10.1016/j.lithos.201 0.08 .016

Lamas, R., Miranda, M., Neves, L., \& Pereira, A. (2015). Radiogenic heat Production from a Deep Borehole in the Beiras Granite (Almeida, Central Portugal). Energy for Sustainability, June, 1-5

Ngadenin, N., Syafeul, H., Widana, K. S., Sukadana, I. G., \& Indrastomo, F. D. (2014). Studi Potensi Thorium pada Batuan Granit di Pulau Bangka. Jurnal Pengembangan Energi Nuklir, 16(2), 143-155

Rybach, L. (1978). The relationship Between Seismic Velocity and Radioactive Heat Production in 
Continental Rocks. Pageoph, 117, 75-82.

Rybach, L., \& Bunterbath, G. (1982). Relationship Between the Petrophysical Properties Density, Seismic Velocity, Heat Generation, and Mineralogical Constitution. Earth and Planetary Science Letters, 57, 335-367-376

Rybach, L., \& Bunterbath, G. (1984). The Variation of Heat Generation, Density and Seismic Velocity with Rock Type in The Continental Lithosphere. Tectonophysics, 103, 335-344

Sclater, J. G., Jaupart, C., \& Galson, D. (1980). The Heat Flow Through Oceanic and Continental Crust and the Heat Loss of the Earth. In Reviews of Geophysics (Vol. 18, Issue 1, pp. 269-311). https://doi.org/10.1029/RG018i001 p00269

Setiawan, K., \& Priadi, B. (2016). Characteristics of Trace Elements in Granitoid Magmatism Discrimination on Bangka Island. Eksplorium, 36(1), 1-16

Singh, L. S., \& Vallinayagam, G. (2016). High Heat Producing VolcanoPlutonic Rocks of the Siner Area, Malani Igneous Suite, Western Rajasthan, India. International Journal of Geoscience, 2012(June), 1-5.

https://doi.org/10.4236/ijg.2012.35

Siregar, R. N., \& Kurniawan, W. B. (2018). 2D Interpretation of Subsurface Hot Spring Geothermal Structure in Nyelanding Village Through Schlumberger Geoelectricity Configuration Method. Jurnal Ilmiah Pendidikan Fisika Al-Biruni, 7(1), 81. https://doi.org/10.24042/jipfalbirun i.v7i1.2324
Sitha, K., \& Setijadji, L. D. (2009). Characteristics of Granitic Rocks of Bangka Island, Indonesia, and Their Associated Mineralization [Universitas Gadjah Mada]. http://etd.repository.ugm.ac.id/hom e/detail_pencarian/43584

Slagstad, T. (2008). Radiogenic Heat Production of Archaean to Permian Geological Provinces in Norway. Norsk Geologisk Tidsskrift, 88(3), 149-166

Widana, K. S. (2013). Petrografi dan Geokimia Unsur Utama Granitoid Pulau Bangka: Kajian Awal Tektonomagmatisme. Eksplorium, 34(2), 1-16

Zhang, C., Hu, S., Zhang, S., Li, S., Zhang, L., Kong, Y., Zuo, Y., Song, R., Jiang, G., \& Wang, Z. (2020). Radiogenic Heat Production Variations in the Gonghe Basin, Northeastern Tibetan Plateau: Implications for the Origin of High-Temperature Geothermal Resources. Renewable Energy, 148(November), 284-297. https://doi.org/10.1016/j.renene.20 19.11.156 